\title{
O ASSOREAMENTO DA BAÍA DE ANTONINA: ASPECTOS NATURAIS E ANTRÓPICOS RELEVANTES PARA A SUA COMPREENSÃO'.
}

\author{
Eduardo Vedor de Paula ${ }^{2}$
}

O processo de assoreamento demonstra-se como sendo natural, sobretudo, em áreas estuarinas e de baía. As atividades antrópicas podem desequilibrar a dinâmica natural, reduzindo a vazão dos cursos d'água ou ampliado a quantidade de sedimentos a serem transportados. Nestas condições o processo de assoreamento pode ser consideravelmente acelerado, tal como vem ocorrendo na Baía de Antonina, que assoreou 6 metros nos últimos 30 anos. A área de abrangência da pesquisa inclui a referida baía, cinco bacias hidrográficas e quatro áreas incrementais, totalizando $1.621,5 \mathrm{~km}^{2}$. Dentre os aspectos físicos verifica-se densa rede hidrográfica carreando sedimentos que vêm de uma região, Serra do Mar, com declividades elevadas e fortes precipitações, além de rochas não consolidadas, como os aluviões e solos propensos à erosão. Diante deste contexto a origem do assoreamento pode ser considerada natural. Entretanto, 0 que se nota é o aumento expressivo da quantidade de sedimentos trazidos pelos rios à baía. As atuações antrópicas, sobretudo, aquelas relacionadas à mudança da cobertura do solo devem ser consideradas. O desmatamento na Serra do Mar e em particular a retirada de matas ciliares em áreas de alta fragilidade ambiental demonstra-se como sendo crescente, em determinadas porções da área de estudo. Salienta-se ainda, a presença do canal de fuga da Usina Hidrelétrica Governador Pedro Viriato. Parigot de Souza, situado na bacia do Rio Cachoeira, que conforme GONÇALVEZ et al. (2005) refere-se à bacia de maior fonte de sedimentos. Para a compreensão dos fatores contribuintes ao assoreamento pretende-se aplicar modelagem hidrológica visando à quantificação da perda de solos nas diferentes bacias hidrográficas. Esta modelagem será implementada em ambiente SIG, quando serão simulados diversos cenários. Cabe salientar que num primeiro momento serão selecionadas áreas pilotos, que sejam representativas à área total, para em seguida modelar-se toda a área estudada.

PALAVRAS-CHAVE: assoreamento; bacia hidrográfica; modelagem hidrológica.

\footnotetext{
${ }^{1}$ Orientador: Prof. Dr. Leonardo Cordeiro dos Santos

2 Doutorando em Geografia (UFPR) - email:eduardovedordepaula@yahoo.com.br
} 